$1-1-1935$

\title{
Some Factors Affecting the Influence of Soybeans, Oats, and Other Crops on the Succeeding Crop
}

David Rollin Dodd,

G. G. Pohlman

Follow this and additional works at: https://researchrepository.wvu.edu/ wv_agricultural_and_forestry_experiment_station_bulletins

\section{Digital Commons Citation}

Dodd, David Rollin and Pohlman, G. G., "Some Factors Affecting the Influence of Soybeans, Oats, and Other Crops on the Succeeding Crop" (1935). West Virginia Agricultural and Forestry Experiment Station Bulletins. 265.

https://researchrepository.wvu.edu/wv_agricultural_and_forestry_experiment_station_bulletins/266 @ WVU. It has been accepted for inclusion in West Virginia Agricultural and Forestry Experiment Station Bulletins by an authorized administrator of The Research Repository @ WVU. For more information, please contact ian.harmon@mail.wvu.edu. 
West Virginia University Libraries

|| || || || || || || |||||||||||| |||

308021005210310 
Digitized by the Internet Archive in 2010 with funding from Lyrasis Members and Sloan Foundation 


\section{Some Factors Affecting the Influence of Soybeans, Oats, and other Crops on the Succeeding Crop}

by D. R. DODD and G. G. POHLMAN 


\section{Agricultural Experimen T Station StafF}

R. A. ARMSTRONG, A. M., L. H. D., Acting President of the University

F. D. FROMME, Ph. D.

Dean and Director

GERALD JENNY, M. S., Agricultural Editor

JOHN C. JOHNSTON, Chief Clerk

\section{AGRONOMY AND GENETICS}

R. J. Garber, Ph. D.

Agronomist and Geneticist

W. H. Pierre, Ph. D.

Associate Agronomist

T. C. Mclvaine, Ph. D.*† Associate Agronomist

G. G Pohlman, Ph, D. Assistant Agronomist

C. R. Burnham, Ph. D. Assistant Geneticist

L. S. Bennett, M. S. Assistant in Agronomy

\section{ANIMAL HUSBANDRY}

E. A. Livesay, D. Sc. Animal Husbandman

C. V. Wilson, M. S. Assistant Animal Husbandman

J. H. Longwell, M. A. Assistant Animal Husbandman

R. H. Tuckwiller, B. S. Agr.* Assistant Animal Husbandman

J. H. Rietz, D. V. M. Associate Veterinarian

E. T. Wightman, M. S. Assistant Poultry Husbandman

T. B. Clark, M. S. Assistant in Poultry Research

\section{CHEMISTRY}

R B. Dustman, Ph. D. Agricultural Chemist

C. E. Weakley, Jr., M. A. Assistant Chemist

A. H. Van Landingham, Ph. D. Assistant Chemist

i. J. Duncan, M. S. Assistant in Agricuitural Chemistry

\section{DA:RY HUSBANDRY}

H. O. Henderson, Ph. D. Da:ry Husbandman

L. M. Thurston, Ph. D. Associate Dairy Husbandman

C. A. Bowling, M. S. Assistant Dairy Husbandman

R. A. Ackerman, M. S. $\ddagger$ Assistant Dairy Husbandman

\section{ENTOMOLOGY}

L. M. Peairs, Ph. D. Entomologist

Edwin Gould, B. S. Agr. Assistant in Entomology

\section{FARM ECONOMICS}

W. W. Armentrout, Ph. D. Farm Economist

F. D. Cornell, Jr., M. S. Assistant Farm Mechanician

R. O. Stelzer, M. S. Assistant Farm Economist

C. H. Bruce, B. S. Assistant in Farm Economics

J. L. Copeman, B. S. Agr. Assistant in Farm Economics

L. F. Herrmann, M. S. Assistant in Farm Economics

HOME ECONOMICS

Rachel H. Colwell, M. A. Home Economist

\section{HORTICULTURE}

H. E. Knowlton, $\mathrm{Ph}$. D. Horticulturist

K. C. Westover, M. S. Assistant Horticulturist

L. P. Batjer, Ph. D. Assistant Horticulturist

E. N. McCubbin, M. A. Assistant in Horticulture

A. P. Dye, M. S. Agr. Assistant in Horticulture

W. H. Childs, M. S. Assistant in Horticulture

\section{PLANT PATHOLOGY}

C. R. Orton, Ph. D Plant Pathologist

L. H. Leonian, Ph. D. Mycologist

Anthony Berg, M. S. Associate Plant Pathologis:

F. J. Schneiderhan, Ph. D. $\dagger \dagger$ Associate Plant Pathologist

Hazel C. Cameron, M. A. Research Speciant in Nutrition

*In cooperation with the U. S. Department of Agriculture, Washington, D. C.

†ln charge of the Lakin Experiment Farm, Lakin, W. Va.

$\ddagger$ ln charge of the Reymann Memorial Farms, Wardensville, W. Va. $\dagger \dagger l n$ charge of the University Experiment Farm, Kearneysville, W. Va. 


\title{
Some Factors Affecting the Influence of Soybeans, Oats, and other Crops on the Succeeding Crop
}

\author{
by D. R. DODD and G. G. POHLMAN*
}

S INCE 1910 soybeans have increased rapidly in popularity as a forage plant and in many sections have largely replaced other annual hay crops. With the increasing demand for legume hay as roughage for livestock, soybeans will probably continue to be important in those regions where large amounts of forage crops are fed. In general, farmers have been well pleased with soybeans but there have been some who report that the crop following soybeans has been poorer than the same crop grown following other crops in their rotation. The effect of soybeans on succeeding crops has been reported by a number of investigators.

Salter (9) in a summary of work at the Ohio Agricultural Experiment Station shows soybeans removed for seed to have caused a lower yield of corn the following year than was obtained following potatoes, timothy, clover, or alfalfa. Under similar conditions potatoes yielded less following soybeans than following corn or clover, and wheat yielded less after soybeans than after corn, oats, alfalfa, clover, or potatoes.

Welton and Morris (12) found wheat to yield better following potatoes, wheat, oats, and clover than following soybeans harvested for seed. They found also a lower nitrate content in the soil following soybeans at wheat-seeding time and suggested that the difference in yisld might be due to difference in nitrate content. However, a lower yield following corn was found even though the nitrate content of the soil was higher.

Deatrick (1) in a greenhouse study found that the yield of wheat was lower following soybeans, but that this decrease was lessened by lengthening the time between harvesting the soybeans and planting the wheat crop. Nitrate of soda applied to the wheat also lessened the effect. He found that the nitrate content of the soil at the time the soybeans were removed was low but increased rapidly. These results indicated that lack of nitrate nitrogen was the cause of the poorer yield.

*A part of these data (1926-1930) has been presented by the senior author, resigned in 1930, in a thesis submitted to Cornell University in partial fulfillment of the requirements for the degree of doctor of philosophy. 
Lyon (4) found that while legumes generally had a tendency to increase the yield of the crop following, soybeans removed for seed had less effect than red, alsike, or sweet clover and alfalfa. Soybeans, even when removed for seed, were superior to both oats and rye in increasing the yield of rye and barley the next year.

McClelland (5) found that the yield of corn following soybeans cut for hay was higher than following oats.

Wiancko, Conner, and Jones (13) found in three experiments that wheat following soybeans harvested for grain yielded better than wheat after corn. The differences for the three tests were 4.4 bushels, 2.6 bushels, and 2.4 bushels, respectively.

Noll and Lewis ( 6 ) found wheat following soybean hay to yield better than wheat following oats. When the soybeans were removed for seed the reverse was true.

Although reports were made by some Illinois farmers that the yield of wheat following soybeans was low, the tests made at Illinois (3) showed soybeans for hay and seed to be superior to corn or oats as a preceding crop for wheat. The yield of wheat following soybeans harvested for seed was poorer than the yield following soybeans harvested for hay but was higher than following corn or oats.

The differences in the results obtained by other investigators point to a need for further studies regarding the effect of soybeans on the yield of succeeding crops. Since soybeans more commonly take the place of oats in the rotation, three experiments were conducted to compare the effects of these two crops on the soil following their removal and on the yield of the succeeding crop.

\section{METHODS}

The field tests were carried out on the Agronomy farm at Morgantown on soil classified as Dekalb silt loam. Laboratory studies of soil moisture, nitrates, and phosphates were made during the first four years of the investigation. The soil samples used were composites of 12 borings taken to a depth of 7 inches, except in plots 101 to 140 . Since these plots were smaller, only 5 borings were taken from each plot. Nitrates were determined colorimetrically by the method described by Schreiner and Failyer (10). All results are expressed as parts per million of dry soil. During 1926, 1927, and 1928 a 1-to-5 extract was obtained by means of a Pasteur Chamberlain filter. In 1929 the collodion sack method used by Pierre and Parker (8) was used to obtain the extract. It was found necessary to add toluene to prevent the reduction of nitrates during the dialysis. Inorganic phosphates were determined by the method described by Parker and Fudge ( 7$)$. 
Crop yields were calculated on the air-dry basis except for potatoes and corn. The corn was recalculated to 14 percent moisture and the potatoes were weighed from the plots as soon as dry and graded.

\section{EXPERIMENT I}

THE EFFECT OF SOYBEANS AND OTHER CROPS ON THE YIELD OF THOSE IMMEDIATELY FOLLOWING AND ON THE NITRATE CONTENT OF THE SOIL

The objects of this experiment were:

(1) to determine the effect of a crop of soybean hay as compared with oats on the yield of corn, wheat, buckwheat, potatoes, and oats following these crops on the same land.

(2) to determine the effect of respective crops of oats, buckwheat, potatoes, wheat, and corn on the yield of following crops of soybeans and oats.

(3) to determine the effect of these various crops and cultural treatments upon the nitrate and moisture contents of the soil, and the relationship of these contents to the yield of crops.

TABLE 1-Plan and cropping scheme of plots 1 to 30 inclusive

\begin{tabular}{|c|c|c|c|}
\hline & \multicolumn{2}{|c|}{$\begin{array}{l}\text { Arrangement of plots and crops } \\
\text { in even years }\end{array}$} & \multirow[t]{2}{*}{$\begin{array}{l}\text { Crops in odd years } \\
\text { for both series } \\
1927,1929,1931 \text {, and } 1933\end{array}$} \\
\hline & $\begin{array}{l}\text { Soybeans in } 1926 \\
\text { Oats in } 1928 \\
\text { Soybeans in } 1930 \\
\text { Oats in } 1932\end{array}$ & $\begin{array}{l}\text { Oats in } 1926 \\
\text { Soybeans in } 1928 \\
\text { Oats in } 1930 \\
\text { Soybeans in } 1932\end{array}$ & \\
\hline \multirow{5}{*}{$\begin{array}{l}-\bar{y} \\
\ddot{y} \\
\frac{0}{0}\end{array}$} & Plot 1 & Plot 16 & Oats \\
\hline & 2 & 17 & Buckwheat \\
\hline & 3 & 18 & Potatoes \\
\hline & 4 & 19 & Wheat \\
\hline & 5 & 20 & Corn \\
\hline \multirow{5}{*}{$\begin{array}{l}N \\
y \\
0 \\
\frac{0}{n}\end{array}$} & 6 & 21 & Oats \\
\hline & 7 & 22 & Buckwheat \\
\hline & 8 & 23 & Potatoes \\
\hline & 9 & 24 & Wheat \\
\hline & 10 & 25 & Corn \\
\hline \multirow{5}{*}{ 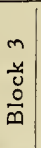 } & 11 & 26 & Oats \\
\hline & 12 & 27 & Buckwheat \\
\hline & 13 & 28 & Potatoes \\
\hline & 14 & 29 & Wheat \\
\hline & 15 & 30 & Corn \\
\hline
\end{tabular}

The plots used in this investigation were 68 feet long by 35 feet wide and were arranged as described in Table 1 . The various crops indicated in this table were seeded and harvested in the usual manner and at the usual time for each respective crop. The yields of the crops are given in Tables A and B (Appendix).

Although the yields obtained were rather variable on account of seasonal conditions, some differences were noted which seemed to warrant further study. In order to determine whether or not 
TABLE 2-Summary and analysis of the effect of oats and soybeans on succeeding crops of oats, buckwheat, potatoes, wheat, and corn

\begin{tabular}{|c|c|c|c|c|c|c|}
\hline Crop & & $\begin{array}{c}\text { Following } \\
\text { oats }\end{array}$ & $\begin{array}{l}\text { Following } \\
\text { soybeans }\end{array}$ & Difference & $\mathrm{P}$ & $\begin{array}{l}\text { Value of } \\
\text { difference }\end{array}$ \\
\hline Oats & $\begin{array}{ll}\text { Crain } & \text { (bu.) } \\
\text { Straw } & \text { (tons) } \\
\end{array}$ & $\begin{array}{c}40.2 \\
0.840 \\
\end{array}$ & $\begin{array}{l}47.6 \\
0.952 \\
\end{array}$ & $\begin{array}{l}7.4 \\
0.112 \\
\end{array}$ & $\begin{array}{l}<0.01 \\
<0.01 \\
\end{array}$ & $\begin{array}{l}\text { Significant } \\
\text { Significant }\end{array}$ \\
\hline Buckwheat & $\begin{array}{ll}\text { Grain } & \text { (bu.) } \\
\text { Straw } & \text { (tons) } \\
\end{array}$ & $\begin{array}{l}30.5 \\
1.224 \\
\end{array}$ & $\begin{array}{l}30.3 \\
1.173\end{array}$ & $\begin{array}{l}0.2 \\
0.051 \\
\end{array}$ & $\begin{array}{l}0.6-0.5 \\
0.2-0.1\end{array}$ & $\begin{array}{l}\text { Not Significant } \\
\text { Not Significant }\end{array}$ \\
\hline Potatoes & Tubers (bu.) & 90.0 & 86.9 & 3.1 & $0.6-0.5$ & Not Significant \\
\hline Wheat & $\begin{array}{l}\text { Grain (bu.) } \\
\text { Straw (tons) }\end{array}$ & $\begin{array}{r}25.1 \\
1.55 \\
\end{array}$ & $\begin{array}{l}28.7 \\
1.77 \\
\end{array}$ & $\begin{array}{l}3.6 \\
0.22 \\
\end{array}$ & $\begin{array}{l}0.02-0.01 \\
0.2-0.1 \\
\end{array}$ & $\begin{array}{l}\text { Significant } \\
\text { Not Significant }\end{array}$ \\
\hline Corn & $\begin{array}{l}\text { Crain (bu.) } \\
\text { Stover (tons) }\end{array}$ & $\begin{array}{l}43.6 \\
1.27 \\
\end{array}$ & $\begin{array}{l}47.6 \\
1.24 \\
\end{array}$ & $\begin{array}{l}4.0 \\
0.03 \\
\end{array}$ & $\begin{array}{c}<0.01 \\
0.4-0.3\end{array}$ & $\begin{array}{l}\text { Significant } \\
\text { Not Sign:ficant }\end{array}$ \\
\hline
\end{tabular}

differences noted were significant, Student's method (11) was used to analyze the data.*

In order to show the effect of oats and soybeans on the succeeding crop the yields, differences, and significance of the differences are given in Table 2.

It may be seen from this table that the yields of oats (both grain and straw), wheat grain, and corn grain are higher following soybeans than following oats, whereas the yields of buckwheat, potatoes, corn stover, and wheat straw are not significantly different.

The data concerning the effect of oats, buckwheat, potatoes, wheat, and corn on yields of soybeans and oats given in Table $B$ (Appendix) are summarized and evaluated according to Student's method in Table 3.

TABLE 3-Summary and analysis of the effect of oats, buckwheat, potatoes, wheat, and con (1928-1932) on succeeding crop of oats and soybeans

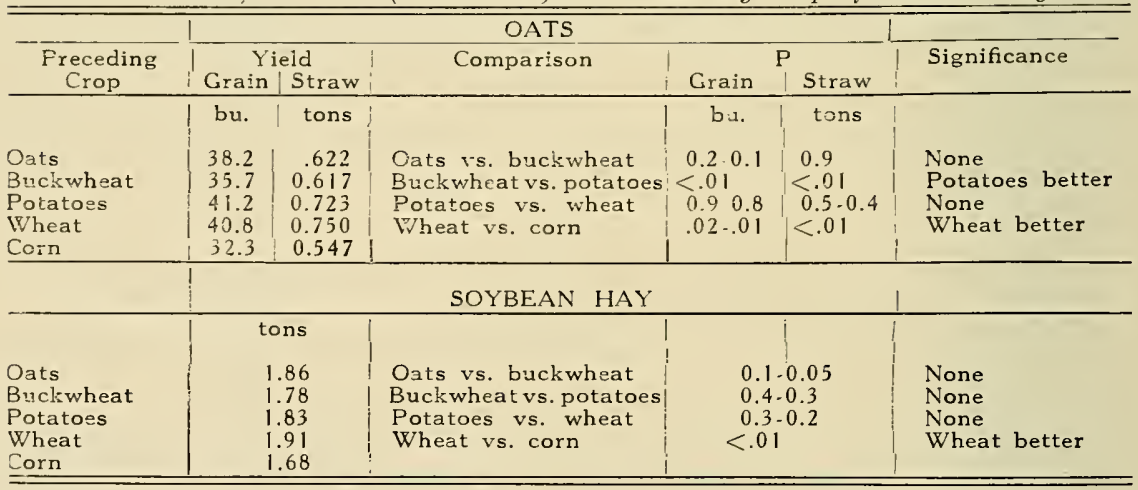

* Inasmuch as the field was variable in fertility, Student's method was applied by pairing the gains or losses on individual plots preceding and following the crop of soybeans or oats. For example, the yield of wheat on plot 4 was 36.5 bu. in 1927 before oats and $28.2 \mathrm{bu}$. in 1929 after oats-a decrease of $8.3 \mathrm{bu}$. due to seasonal conditions and cropping. On the adjacent plot 19 the yield of wheat was $35.3 \mathrm{bu}$. in 1927 before soybeans and $26.4 \mathrm{bu}$. in 1929 after soybeans-a decrease of $8.9 \mathrm{bu}$. due to seasonal conditions and cropping. By comparing the difference, 8.3 bu. and 8.9 bu., seasonal conditions are eliminated and the loss of $0.6 \mathrm{bu}$. is attributed to the previous crop of soybeans. This method of application of Student's method was followed only in the analyses given in Table 2 ; in other calculations Student's original method was used. $P$ values were obtained by the method given by Fisher (2). 
It may be seen from these comparisons that wheat is better than corn and that potatoes are better than buckwheat as preceding crops for oats. Since all treatments are not adjacent, direct comparisons by Student's method of each crop with every other crop are not possible from the data given. However, it is evident that better yields of oats were obtained following wheat or potatoes than yields following corn, oats, or buckwheat. In regard to the effect of preceding crops on soybeans, wheat gave better results than corn, but the differences in the other crops are too small to be considered important.

Inasmuch as certain investigators have found a relationship to exist between the effect of one crop upon another and the supply of nitrate nitrogen, it was thought desirable to study the nitrate content of the soil during and following the growth of the crops tested.

The production of nitrate nitrogen in the soil (known as nitrification) is dependent on a number of factors, among which may be listed the following:

(1) The amount of nitrogon in the soil which can easily be changed to nitrates. The production of nitrates is brought about by certain bacteria which can use nitrogen only in the form of ammonia. The ammonia is in turn produced by other microorganisms from the proteins supplied to the soil by crop residues. Leguminous plants are higher in protein than non-legumes and conscquently furnish more available nitrogen for the production of nitrates.

(2) The aeration of the soil. Stirring the soil as is done in cultivation of crops or in preparing the seedbed increases the amount of air present in the soil and thus increases the activity of the bacteria which produce nitrates.

(3) The moisture content of the soil. The bacteria responsible for nitrification are active over a wide range of moisture content and it is only at the extremes of moisture content that water exerts much influence. A proper balance between moisture and air is necessary for the production of nitrates.

(4) The acidity of the soil. The acidity of sourness of the soil is a very important factor in determining the amount of nitrates produced. The lower the acidity or lime requirement, the greater the production of nitrates. However, in these experiments there were only slight differences in lime requirement and, because of the methods used. these were not a factor.

(5) The soil temperature. In West Virginia the maximum nitrification takes place during the hot summer months, since the bacteria are most active at relatively high soil temperatures. This accounts for the high nitrate concentrations found during the summer. 
In addition to these factors which regulate the production of nitrates, the losses of nitrates are important in determining the amounts actually present in the soil at a given time. Among these may be listed the following:

(1) Crop removal. All common crops grown in West Virginia utilize nitrates during their growing period, the most rapid utilization being during their most active growth. As shown in the following discussion the low nitrate contents found at certain samplings may be accounted for by this removal.

(2) Leaching. Nitrates are readily dissolved in water and may be leached or washed from the soil during rains.

(3) Utilization of nitrates by microorganisms. The decomposition processes occurring in the soil are brought about by bacteria which feed on nitrates much as plants do. The loss of nitrates from this source is most important when plants or residues low in nitrogen are incorporated with the soil.

TABLE 4-Nitrate content of soil on oats and soybean plots in 1928*

\begin{tabular}{|c|c|c|c|c|c|c|}
\hline \multirow[b]{2}{*}{ Date sampled } & \multirow{2}{*}{$\begin{array}{c}\text { Crop grown } \\
\text { the year } \\
\text { sampled** }\end{array}$} & \multicolumn{5}{|c|}{ Crop grown the previous year } \\
\hline & & $\begin{array}{l}1927 \\
\text { Oats } \\
\end{array}$ & $\begin{array}{c}1927 \\
\text { Buckwheat }\end{array}$ & $\begin{array}{c}1927 \\
\text { Potatoes }\end{array}$ & $\begin{array}{l}1927 \\
\text { Wheat }\end{array}$ & $\begin{array}{c}1927 \\
\text { Corn } \\
\end{array}$ \\
\hline & & p.p.m. & p.p.m. & p.p.m. & p.p.m. & p.p.m \\
\hline April & Oats & 14.9 & 17.7 & 13.3 & 11.7 & 10.5 \\
\hline 6 & Soybeans & 11.7 & 13.5 & 18.8 & 9.2 & 10.0 \\
\hline May & Oats & 15.8 & 11.2 & 16.2 & 17.2 & 11.7 \\
\hline 18 & Soybeans & 41.4 & 33.0 & 30.1 & 38.1 & 32.4 \\
\hline July & Oats & 4.9 & 4.2 & 5.2 & 5.0 & 3.9 \\
\hline 11 & Soybeans & 5.0 & 4.4 & 4.5 & 4.4 & 3.3 \\
\hline August & Oats & 8.9 & 10.5 & 8.0 & 9.3 & 10.8 \\
\hline 8 & Soybeans & 7.6 & 6.3 & 7.3 & 9.0 & 5.9 \\
\hline September & Oats & 3.4 & 3.0 & 3.0 & 2.8 & 2.6 \\
\hline 12 & Soybeans & 38.2 & 29.7 & 27.3 & 32.9 & 27.7 \\
\hline September & Oats & 8.1 & 6.9 & 7.4 & 21.2 & 5.1 \\
\hline 25 & Soybeans & 52.3 & 42.7 & 45.5 & 74.8 & 47.7 \\
\hline
\end{tabular}

*Average of three plots.

**Oats planted April 7; soybeans planted May 18.

Nitrate determinations were made at intervals during 1928 and 1929. These data are presented in Tables 4 and 5.

The effect of the soybeans in reducing the nitrate content of the soil is shown in Table 4. For example, it will be noted that on July 11 the nitrate content varied from 3.3 to 5.0 p.p.m., whereas on May 18, before this crop was planted, the nitrate content varied from 30.1 to 41.4. Oats showed a somewhat smaller reduction in 1928. The reduction is further shown for oats, buckwheat, and wheat in Table 5, in which the lowest nitrate content of the soils appeared on June 25, August 30, and May 16, respectively. These correspond to the time when the plants were actively growing. The nitrate content of the cultivated crops does not reach as low a level during the summer despite the use by the crop, the lowest value being 12.2 p.p.m. on corn on July 30 . This is true because of the more favorable condition for nitrate production in cultivated soils. 
The effect of the residues of the preceding crop on soil nitrates is shown by the increase in nitrate content in the fall shortly after the removal of the crop. In Table 4 it may be noted that the nitrate content of the soil following the removal of soybeans increased much more rapidly than following the removal of oats. The residue from leguminous crops decomposes more rapidly in the soil than does the residue from non-legumes. Since legumes are higher in nitrogen they would be expected to allow a more rapid accumulation of nitrates. The utilization of nitrates by weeds growing on the oats plots after the oat crop was harvested probably accounts for some of the differences.

TABLE 5-Nitrate content of soil on plots in various crops in 1929*

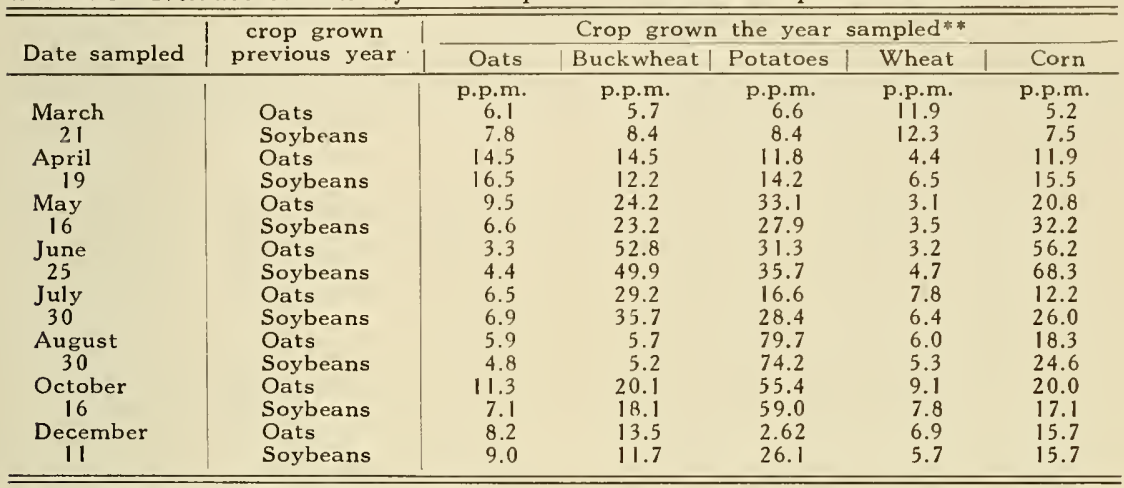

*Average of three plots.

**Oats planted April 6, harvested July 17.

Buckwheat planted July 1, harvested Sept. 14.

Potatoes planted April 20, harvested Aug. 13.

Wheat planted Sept. 26, 1928, harvested July 9.

Corn planted May 10, harvested Oct, 10.

The data for October 16 in Table 5 show the highest nitrate content following potatoes (57.2 p.p.m.); then buckwheat (19.1 p.p.m.), corn (18.55 p.p.m.), oats (9.2 p.p.m.), and wheat (8.55 p.p.m.) follow in the order given. The high content following potatoes can be accounted for by their early removal, the small amount of residue left in the soil, and the fact that they are a cultivated crop. The other cultivated crop, corn, was not removed until later in the season, which accounts for its lower rank in nitrate content. The growth of weeds probably accounts in part for the low values for wheat and oats.

The effect of cultural practices has already been suggested in comparing cultivated and non-cultivated crops. This is also evident in Table 4, which shows that the plots planted to wheat were much higher in nitrates on September 25 than any of the other plots. This was undoubtedly the result of cultural practices used in the preparation of the seed bed.

Inasmuch as attempts have been made to correlate yield with nitrate content it is of interest to compare these data as presented 
in the preceding tables. It has already been noted that the nitrate content of the soil was higher in the fall following soybeans than following oats. The increase in wheat yield which was noted in Table 2 and which occurred in three of the four years (Table A) may have been the result of the higher nitrate content in the fall. In the spring higher nitrate content appeared only on the corn plots following soybeans, and this may have been a factor in increasing the corn yield. The higher vield of oats following soybeans than following oats was probably the result of continuous cropping-a practice which has long been known to be undesirable. No differences in nitrate content or yield were noted with either buckwheat or" potatoes.

\section{EXPERIMENT II}

THE EFFECT OF THE DATE OF REMOVAL OF SOYBEANS ON THE YIELD OF FOLLOWING CROPS AND ON NITRATE CONTENT OF SOIL

The objects of Experiment II were:

(1) To study the influence of different periods of fallow after soybean removal upon the yields of corn and wheat following.

(2) To study the relationship of the moisture and nitrate content of the soil to the corn and wheat yields.

(3) To determine the course of the nitrate content of the soil during the growth and following the removal of crops of soybeans, corn, and wheat.

This part of the investigation involves 24 1-40 acre plots numbered 31 to 54 inclusive. The soil ranges from a Dekalb silt loam to a Dekalb fine sandy loam and is below average in productivity. This land had not been farmed for some years before being used for this investigation. At the beginning of the experiment it was rather uniformly covered with a mixture of cinquefoil (Potentilla L.), poverty grass (Danthonia spicata L.), bent grasses (Agrostis L.), and broom sedge (Andropogon furcatus Muhl). A lime requirement test by the Truog method was made in the spring of 1926, and 4500 pounds of hydrated lime per acre were applied at that time. Colorimetric determinations in the fall of 1929 showed $\mathrm{pH}$ values ranging generally around 5.6. A uniform treatment of 400 pounds of 16 percent superphosphate was given to all plots in the spring of $1926,1928,1930$, and 1932 . No other fertilizer was used.

The plan and cropping scheme of the plots of this expariment are given in Table 6.

The yields of soybeans for 1926, 1928, 1930, and 1932 are presented in Table $C$ (Appendix). Although it has no connection with this experiment, it is of interest to note the effect of date of removal on the amount of soybean hay produced. The average yields obtained were: 0.965 tons for the cutting on August $10 ; 1.419$ tons 
TABLE 6-Plan and cropping scheme of plots 31 to $5 l_{4}$ inclusive

Arrangement of plots and crops

$$
\text { in odd years }
$$

Corn 1927

Wheat 1929

Corn 1931

Wheat 1933

Plot 3

Plot 32

Plot 34

Plot 35

Plot 36

Plot 37

Plot 38

Plot 39

Plot 40

Plot 41

Plot 42

\author{
Wheat 1927 \\ Corn 1329 \\ Wheat 1931 \\ Corn 1933
}

Plot 43

Plot 44

Plot 45

Plot 4 's

Plot 47

Plot 48

Plot 49

Plot 50

Plot 51

Plot 52

Plot 53

Plot 54
Crops and treatment in even years, both series

Soybsans removed August 10,1926

September 25, 1928; August 30, 1930; August 10, 1932

Soybeans removed August 30, 1926;

August 10, 1928; September 20, 1930; A:igust $30, \quad 1932$.

So beans removed Sept. 20, 1926;

A."cgust 30, 1929; August 10, 1930; 5. 3t. 20,1932

"sybeans removed August 10, 1926; September 25, 1928; August 30, 1930; August 10, 1932

Soybeans removed August 30, 1926;

August 10, 1928; September 20, 1930 ;

August 30,1932

Soybeans removed September 20, 1926 ;

August 30, 1928; August 10, 1930; September 20, 1932

Soybeans removed August 10, 1926; September 25, 1928; August 30, 1930; August 10, 1932

Soybeans removed August 30, 1926:

August 10, 1928; September 20, 1930; August 30,1932

Soybeans removed September 20, 1926 August 30, 1928; August 10, 1930. September 20, 1932.

Soybeans removed August 10, 1926; September 25, 1928; August 30, 1930 ; August 10, 1932

Soybeans removed August 30, 1926;

August 10, 1928; September 20, 1930 . August 30,1932

Soybeans removed September 20, 1926 ;

August 30, 1928; August 10, 1930.

September 20, 1932

TABLE 7-Effect of date of removal of soybeans on yield of wheat

\begin{tabular}{|c|c|c|c|c|c|c|}
\hline \multirow{2}{*}{$\frac{\text { Date removed }}{\text { Year }}$} & \multicolumn{2}{|c|}{ August 10} & \multicolumn{2}{|c|}{ August 30} & \multicolumn{2}{|c|}{ September 20} \\
\hline & Grain & Straw & Grain & Straw & Grain & Straw \\
\hline 1927 & $\begin{array}{l}\text { Bu. } \\
27.5 \\
18.2 \\
18.6 \\
22.8\end{array}$ & $\begin{array}{r}\text { Tons } \\
1.495 \\
.964 \\
1.117 \\
1.285\end{array}$ & $\begin{array}{l}\text { Bu. } \\
23.3 \\
21.4 \\
19.5 \\
23.3\end{array}$ & $\begin{array}{l}\text { Tons } \\
1.285 \\
1.062 \\
0.978 \\
1.215\end{array}$ & $\begin{array}{l}\text { Bu. } \\
18.6 \\
18.6 \\
18.6 \\
18.2\end{array}$ & $\begin{array}{r}\text { Tons } \\
.978 \\
.894 \\
1.103 \\
.936\end{array}$ \\
\hline 1929 & $\begin{array}{l}20.9 \\
20.5 \\
22.3 \\
17.3\end{array}$ & $\begin{array}{r}1.012 \\
.958 \\
1.039 \\
.850\end{array}$ & $\begin{array}{l}19.1 \\
19.6 \\
23.7 \\
20.0\end{array}$ & $\begin{array}{r}.891 \\
.918 \\
1.161 \\
.918\end{array}$ & $\begin{array}{l}19.6 \\
16.8 \\
18.2 \\
20.0\end{array}$ & $\begin{array}{l}.945 \\
.769 \\
.823 \\
.985\end{array}$ \\
\hline 1931 & $\begin{array}{l}12.7 \\
12.7 \\
18.2 \\
13.6\end{array}$ & $\begin{array}{l}.573 \\
.573 \\
.764 \\
.600\end{array}$ & $\begin{array}{l}20.5 \\
10.9 \\
12.3 \\
20.0\end{array}$ & $\begin{array}{l}.846 \\
.464 \\
.532 \\
.887\end{array}$ & $\begin{array}{r}10.9 \\
8.2 \\
10.9 \\
15.5\end{array}$ & $\begin{array}{l}.464 \\
.355 \\
.300 \\
.682\end{array}$ \\
\hline 1933 & $\begin{array}{l}27.3 \\
27.3 \\
26.8 \\
23.2\end{array}$ & $\begin{array}{l}1.473 \\
1.500 \\
1.432 \\
1.432\end{array}$ & $\begin{array}{l}24.1 \\
25.5 \\
22.3 \\
23.6\end{array}$ & $\begin{array}{l}1.269 \\
1.323 \\
1.050 \\
1.337\end{array}$ & $\begin{array}{l}25.0 \\
23.2 \\
24.1 \\
22.7\end{array}$ & $\begin{array}{l}1.350 \\
1.269 \\
1.323 \\
1.255\end{array}$ \\
\hline Average & 20.62 & 1.067 & 20.57 & 1.008 & 18.07 & 0.902 \\
\hline
\end{tabular}


for the cutting on August 30; and 1.521 tons for the cutting on September 20.

Data showing the effect of time of removal of soybeans on the yield of wheat the following year are given in Table 7 . The average yields were 20.62 bu., 20.57 bu., and $18.07 \mathrm{bu}$., on the plots from which soybeans were removed August 10, August 30, and September 20, respectively. Analysis of these data by Student's method brings out the following points:

(1) Plots from which the soybeans were harvested September 20 gave lower yields of wheat grain than did either of the plots harvested earlier. The differences of about $21 / 2$ bushels gave $P$ values of $0.05-0.02$ and $<0.01$ respectively for the comparisons with August 10 and August 30.

(2) The yield of wheat straw was also lower on the plot harvested September $20 \quad(\mathrm{P}=0.5-0.2)$.

(3) There was little difference in yield of wheat grain when soybeans were harvested August 10 and August 30 $(\mathrm{P}=0.5-0.4)$.

(4) The yield of straw was somewhat higher when soybeans were harvested August 10 than when harvest was delayed until August $30(\mathrm{P}=0.05-0.02)$.

Reasons for these differences will be discussed after the presentation of the data on nitrate content of the soils.

The yield of corn on plots from which soybeans were removed at different dates the previous year is given in Table 8 . The average yield of 47.71 bu., 45.61 bu., and 47.22 bu., as shown at the bot-

TABLE 8-Effect of date of removal of soybeans on yield of succeeding corn crop

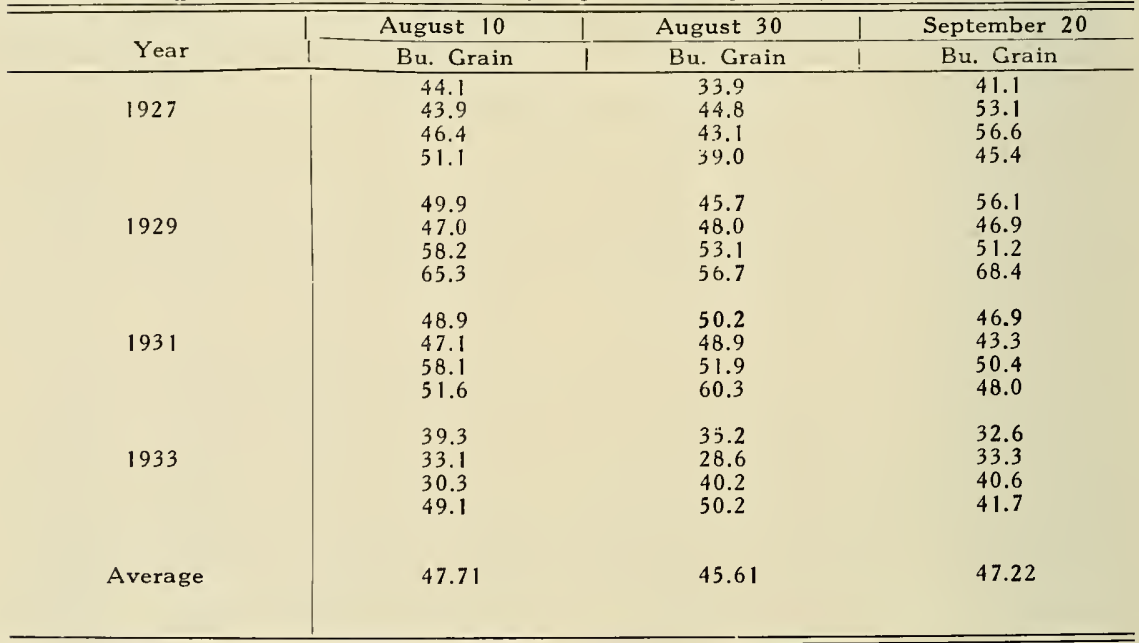


tom of the table show little difference in yield of corn regardless of the time of removal of the soybeans. This is borne out by a statistical analysis of the data, which show that there are no significant differences in yield ( $\mathrm{P}$ values $0.2-0.1,0.3-0.2$, and $0.6-0.5$ ) in the comparisons between August 10 and August 30, August 30 and September 20, and August 10 and September 20, respectively.

\section{NITRATE AND MOISTURE CONTENT OF SOIL FOLLOWING REMOVAL OF SOYBEANS AT DIFFERENT DATES}

As in Experiment I, soil samples for nitrates and moisture determinations were taken at intervals during the first four years of the experiment. A summary of the data obtained is given in Table 9. This table shows that the nitrate content of the soil was very low during the growth of soybeans in 1926, but that it increased

TABLE 9-Nitrate content of soils after removal of soybeans

\begin{tabular}{|c|c|c|c|c|c|c|}
\hline \multirow{3}{*}{$\begin{array}{c}\text { Date of } \\
\text { sampling }\end{array}$} & \multicolumn{3}{|c|}{ Corn 1927} & \multicolumn{3}{|c|}{ Wheat 1927} \\
\hline & \multicolumn{3}{|c|}{ Date of soybean harvest } & \multicolumn{3}{|c|}{ Date of soybean harvest } \\
\hline & $8-10-26$ & $8-30-26$ & $9-20-26$ & $8-10-26$ & $8-30-26$ & $9-20-26$ \\
\hline \multirow[t]{2}{*}{$\begin{array}{r}8-13-26 \\
8-31-26 \\
9-22-26 \\
11-29-26 \\
4-15-27 \\
6-9-27 \\
7-21-27 \\
\end{array}$} & $\begin{array}{c}\text { p.p.m. } \\
2.0 \\
4.5 \\
9.1 \\
6.9 \\
3.1 \\
46.0 \\
90.5 \\
\end{array}$ & $\begin{array}{c}\text { p.p.m. } \\
2.1 \\
2.4 \\
9.6 \\
5.8 \\
3.2 \\
47.2 \\
95.9\end{array}$ & $\begin{array}{c}\text { p.p.m. } \\
2.0 \\
2.1 \\
3.4 \\
5.9 \\
3.8 \\
44.6 \\
93.3\end{array}$ & $\begin{array}{c}\text { p.p.m. } \\
1.8 \\
5.3 \\
4.8 \\
5.5 \\
2.4 \\
3.8 \\
2.7\end{array}$ & $\begin{array}{c}\text { p.p.m. } \\
1.9 \\
2.6 \\
5.4 \\
5.7 \\
2.4 \\
2.5 \\
3.3\end{array}$ & $\begin{array}{c}\text { p.p.m. } \\
1.8 \\
2.8 \\
3.1 \\
5.4 \\
2.4 \\
2.3 \\
2.9\end{array}$ \\
\hline & \multicolumn{3}{|c|}{ Corn 1929} & \multicolumn{3}{|c|}{ Wheat 1929} \\
\hline $\begin{array}{r}7-11-28 \\
8-10-28 \\
8-30-28 \\
9-25-28 \\
10-16-28 \\
11-16-28 \\
4-19-29 \\
5-16-29 \\
6-24-29 \\
7-1-29 \\
7-30-29 \\
8-30-29 \\
10-17-29 \\
12-11-29\end{array}$ & $\begin{array}{r}4.0 \\
1.7 \\
9.9 \\
13.1 \\
4.8 \\
(*) \\
3.3 \\
15.2 \\
(*) \\
57.2 \\
24.0 \\
7.7 \\
6.5 \\
9.2\end{array}$ & $\begin{array}{r}3.5 \\
1.5 \\
0.6 \\
8.2 \\
9.3 \\
\left.1^{*}\right) \\
4.3 \\
18.7 \\
(*) \\
60.9 \\
26.5 \\
17.0 \\
13.0 \\
8.9\end{array}$ & $\begin{array}{r}3.9 \\
1.6 \\
1.4 \\
1.6 \\
3.7 \\
(*) \\
9.1 \\
23.9 \\
(*) \\
54.2 \\
22.8 \\
20.0 \\
13.4 \\
12.4\end{array}$ & $\begin{array}{r}5.6 \\
1.8 \\
24.7 \\
36.9 \\
29.0 \\
35.0 \\
4.1 \\
2.6 \\
5.7 \\
4.0 \\
4.9 \\
3.2 \\
4.0 \\
4.3\end{array}$ & $\begin{array}{r}7.4 \\
1.9 \\
2.3 \\
18.8 \\
25.1 \\
30.5 \\
4.7 \\
2.9 \\
6.7 \\
5.1 \\
9.8 \\
4.9 \\
4.9 \\
4.5\end{array}$ & $\begin{array}{r}6.7 \\
2.2 \\
2.8 \\
2.6 \\
7.2 \\
13.3 \\
6.8 \\
2.7 \\
5.8 \\
5.6 \\
4.7 \\
3.6 \\
6.2 \\
5.4\end{array}$ \\
\hline
\end{tabular}

(*) Not determined.

very soon after their removal. The actual increase was small because of rain immediately before sampling, but it represents a high percentage increase. The different dates of harvesting also had a distinct effect on the nitrate content. The plots from which soybeans were removed on August 10 more than doubled in their nitrate content in the first 21 days after the removal of soybeans. The same was true of the plots from which soybeans were removed on August 30. The plots harvested September 20 did not show much increase in nitrate content, probably because wheat was planted a few days later and the growing wheat plants utilized the nitrates produced.

At the time of seeding wheat on September 22, the plots from which soybeans had been removed on August 10 and August 30 contained about $11 / 2$ times the quantity of nitrates found in those 
from which soybeans were removed on September 20. These differences did not continue long and by the last of November were not evident.

In 1928 the nitrate content of the soil was also very low during the growth of soybeans, but it again increased rapidly after their removal. The different dates of harvesting also had the same effect as in 1926. There were very significant differences for the different harvest dates at the time of seeding wheat on September 26, as shown in Figure 1. These differences, however, were reduced during the following winter.

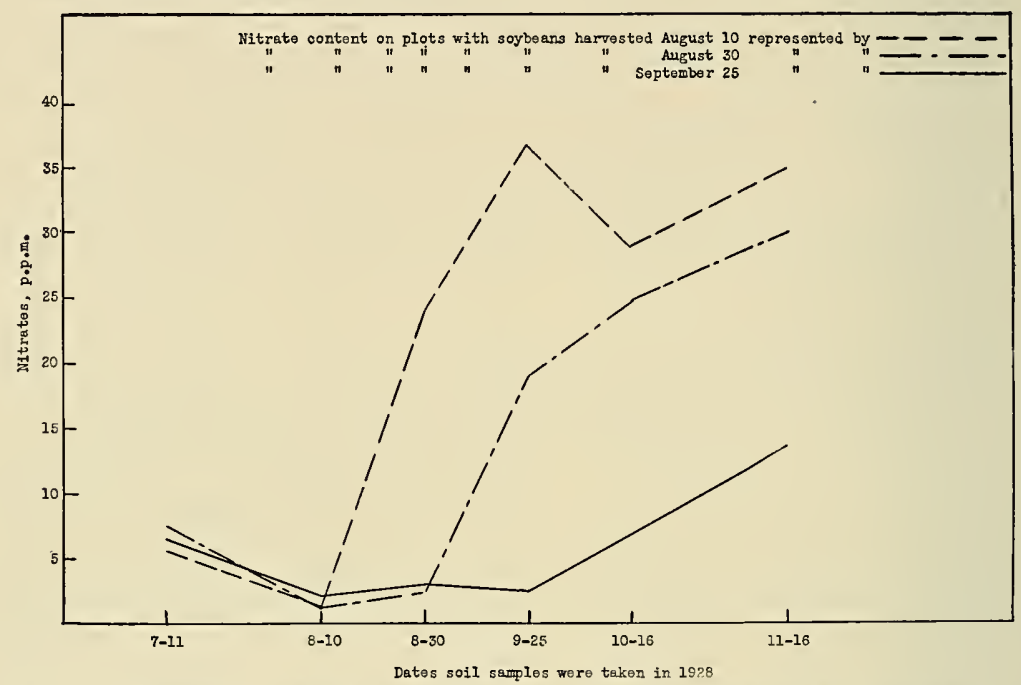

FIG. 1-Effect of date of harvesting soybeans on the nitrate content of the soil. All plots seeded to wheat September 28, 1928

A comparison of wheat yields as given in Table 7 with the nitrate content figures as given in Table 9 reveals a close agreement between wheat yields and nitrate content. The lowest wheat yield in 1927 was associated with the lowest soil nitrate content during the fall of 1926, when the wheat was getting started. The highest wheat yield for the same year was associated with the highest nitrate content. The effect of the nitrate was also very evident in the field. The wheat on the plots from which soybeans were last removed and when the nitrate content was lowest started off slowly and had poor color, while that on the other plots from which soybeans had been removed earlier started off more rapidly with a deeper green color. The same condition prevailed in 1929, and again the high yield was associated with the high nitrate content and the low yield with the low nitrate content. It is noteworthy that this agreement is limited to the fall. During the next season a reverse condition prevailed. In the spring of 1927, and again in 1929, the 
wheat plots which had been slow in starting during the fall and where the color had been poor, took on a deeper green color and were slower to mature at harvest time. The high yield, however, was associated with the high nitrate content of the soil at planting rather than at harvest time.

In the corn plots differences in nitrate content were not evident in the spring at planting time, nor was there any effect of date of removal of soybeans on the yield. The time elapsed between the harvesting of the soybeans and the planting of the corn was sufficient to allow the decomposition of the soybean residue and the accumulation of the nitrates necessary to start the corn crop.

TABLE 10-Moisture and nitrate content of soil and yield of wheat for plots 31-42, 1928-29, grouped according to treatment

\begin{tabular}{lccccc}
\hline & $\begin{array}{c}10-16-28 \\
\text { Nitrates }\end{array}$ & $\begin{array}{c}10-16-20 \\
\text { Moisture }\end{array}$ & $\begin{array}{c}11-16-28 \\
\text { Nitrates }\end{array}$ & $\begin{array}{c}11-16.28 \\
\text { Moisture }\end{array}$ & $\begin{array}{c}\text { Yield of } \\
\text { wheat, 1929 }\end{array}$ \\
\hline $\begin{array}{l}\text { Soybeans removed Aug. 10 } \\
\text { Plots 32, 35, 38, 41 }\end{array}$ & p.p.m. & $\%$ & p.p.m. & $\%$ & bu. \\
$\begin{array}{l}\text { Soybeans removed Aug. 10 } \\
\text { Plots 33, 36, 39, 42 }\end{array}$ & 29.0 & 15.0 & 35.0 & 20.9 & 20.2 \\
$\begin{array}{l}\text { Soybeans removed Sept. 25 } \\
\text { Plots 31, 34, 37, 40 }\end{array}$ & 25.1 & 15.1 & 30.5 & 20.4 & 20.6 \\
\hline \hline
\end{tabular}

It was noted in the course of this investigation that the growing of soybeans seemed to affect the physical condition of the soil. This being true, the question arose as to whether the different dates of harvesting the soybeans might not affect the moisture content of the soil. There appeared in the fall of 1928 to be a difference in moisture content in plots $31-42$, which had been seeded to wheat following soybeans harvested at different dates. Nitrate and moisture contents were determined on October 16 and again on November 16, thus making possible a comparison between these and the date of harvesting and also between both of these factors and the yield of the following wheat crop. The data, presented in Table 10, show a very close relationship between nitrate content, moisture content, and yield of wheat. There appears also a very close relationship between each of these and the date of harvesting soybean hay. While there is little difference between August 10 data and those of August 30, there is a very significant difference between those of August 10 and September 25.

The absence of significant difference between the data for plots where soybeans were removed August 10 and where they were removed August 30 may be explained by the amount of time which had elapsed between these harvest dates and the time of sampling for these determinations. The periods from August 10 and $\mathrm{Au}$ gust 30 to October 16 were both sufficient to permit fair equilibrium to become established. The period from September 25 to October 16 was not. 


\section{EXPERIMENT III}

\section{COUNTERACTING THE DEPRESSING EFFECT OF THE LATE REMOVAL OF SOYBEANS}

From the data obtained in Experiment II it soon was evident that the late removal of soybeans had a depressing effect on the yield of wheat the following year. Inasmuch as these differences in yield appeared to be related to the nitrate and moisture content of the soil, an experiment was planned to determine which of these factors might be responsible for the lowered wheat yields following late removal of the soybeans, and how this effect could be overcome.

TABLE 11-Plan and treatment scheme of plots 101 to 140 inclusive*

\begin{tabular}{|c|c|c|c|c|c|}
\hline $\begin{array}{l}\text { Plot No. } \\
\text { Date of soybean harvest } \\
\text { Treatment before wheat }\end{array}$ & $\begin{array}{c}101 \\
\text { Sept. } 20 \\
250= \\
\mathrm{NaNO}_{3}\end{array}$ & $\begin{array}{c}109 \\
\text { Sept. } 20 \\
50= \\
\mathrm{NaNO}_{3}\end{array}$ & $\begin{array}{l}117 \\
\text { Aug. } 10 \\
\ldots\end{array}$ & $\begin{array}{l}125 \\
\text { Sept. } 20 \\
\text { Pack }\end{array}$ & $\begin{array}{l}133 \\
\text { Sept. } 20 \\
400 \neq \\
2.14-4\end{array}$ \\
\hline $\begin{array}{l}\text { Plot No. } \\
\text { Date of soybean harvest } \\
\text { Treatment before wheat }\end{array}$ & $\begin{array}{c}102 \\
\text { Aug. } 10 \\
\ldots\end{array}$ & $\begin{array}{l}110 \\
\text { Sept. } 20 \\
\text { Pack }\end{array}$ & $\begin{array}{c}118 \\
\text { Sept. } 20 \\
\text { Pack } \\
150 \pm \mathrm{NaNO}\end{array}$ & $\begin{array}{l}126 \\
\text { Sept. } 20 \\
50 \neq \\
\mathrm{NaNO}_{3}\end{array}$ & $\begin{array}{l}134 \\
\text { Sept. } 20 \\
250 \pm \\
\mathrm{NaNO}_{3}\end{array}$ \\
\hline $\begin{array}{l}\text { Plot No. } \\
\text { Date of soybean harvest } \\
\text { Treatment before wheat }\end{array}$ & $\begin{array}{c}103 \\
\text { Sept. } 20 \\
\text { Pack } 150 \pm \\
\mathrm{NaNO}_{3}\end{array}$ & $\begin{array}{l}111 \\
\text { Sept. } 20 \\
250 \pm \\
\mathrm{NaNO}_{3}\end{array}$ & $\begin{array}{l}119 \\
\text { Sept. } 20 \\
\text { Pack }\end{array}$ & $\begin{array}{l}127 \\
\text { Sept. } 20 \\
\ldots\end{array}$ & $\begin{array}{l}135 \\
\text { Sept. } 20 \\
50 \pm \\
\mathrm{NaNO}_{3}\end{array}$ \\
\hline $\begin{array}{l}\text { Plot No. } \\
\text { Date of soybean harvest } \\
\text { Treatment before wheat }\end{array}$ & $\begin{array}{l}104 \\
\text { Sept. } 20 \\
150= \\
\mathrm{NaNO}_{3}\end{array}$ & $\begin{array}{l}112 \\
\text { Sept. } 20 \\
400= \\
2.14-4\end{array}$ & $\begin{array}{l}120 \\
\text { Sept. } 20 \\
50 \% \\
\mathrm{NaNO}_{3}\end{array}$ & $\begin{array}{c}128 \\
\text { Sept. } 20 \\
\text { Pack } \\
150=\mathrm{NaNO}_{3}\end{array}$ & $\begin{array}{l}136 \\
\text { Sept. } 20 \\
\text { Pack }\end{array}$ \\
\hline $\begin{array}{l}\text { Plot No. } \\
\text { Date of soybean harvest } \\
\text { Treatment before wheat }\end{array}$ & $\begin{array}{c}105 \\
\text { Sept. } 20 \\
400= \\
2.14-4\end{array}$ & $\begin{array}{c}113 \\
\text { Sept. } 20 \\
\text { Pack } \\
150 \neq \mathrm{NaNO}_{3}\end{array}$ & $\begin{array}{c}121 \\
\text { Sept. } 20 \\
150 \neq \\
\mathrm{NaNO}_{3}\end{array}$ & $\begin{array}{c}129 \\
\text { Aug. } 10 \\
\ldots \ldots\end{array}$ & $\begin{array}{l}137 \\
\text { Sept. } 20 \\
\ldots\end{array}$ \\
\hline $\begin{array}{l}\text { Plot No. } \\
\text { Date of soybean harvest } \\
\text { Treatment before wheat }\end{array}$ & $\begin{array}{l}106 \\
\text { Sept. } 20 \\
50 \pm \\
\mathrm{NaNO}_{3}\end{array}$ & $\begin{array}{l}114 \\
\text { Aug. } 10 \\
\ldots\end{array}$ & $\begin{array}{l}122 \\
\text { Sept. } 20 \\
\ldots\end{array}$ & $\begin{array}{l}130 \\
\text { Sept. } 20 \\
150 \ddagger \\
\mathrm{NaNO}_{3}\end{array}$ & $\begin{array}{c}138 \\
\text { Sept. } 20 \\
\text { Pack } \\
150 \pm \mathrm{NaNO}_{2}\end{array}$ \\
\hline $\begin{array}{l}\text { Plot No. } \\
\text { Date of soybean harvest } \\
\text { Treatment before wheat }\end{array}$ & $\begin{array}{l}107 \\
\text { Sept. } 20 \\
\ldots\end{array}$ & $\begin{array}{l}115 \\
\text { Sept. } 20 \\
150 \pm \\
\mathrm{NaNO}_{3}\end{array}$ & $\begin{array}{l}123 \\
\text { Sept. } 20 \\
250 \pm \\
\mathrm{NaNO}_{3}\end{array}$ & $\begin{array}{c}131 \\
\text { Sept. } 20 \\
400 \% \\
2-14-4\end{array}$ & $\begin{array}{l}139 \\
\text { Aug. } 10 \\
\ldots\end{array}$ \\
\hline $\begin{array}{l}\text { Plot No. } \\
\text { Date of soybean harvest } \\
\text { Treatment before wheat }\end{array}$ & $\begin{array}{l}108 \\
\text { Sept. } 20 \\
\text { Pack }\end{array}$ & $\begin{array}{l}116 \\
\text { Sept. } 20 \\
\ldots\end{array}$ & $\begin{array}{l}124 \\
\text { Sept. } 20 \\
400 \sharp \\
2-14-4\end{array}$ & $\begin{array}{c}132 \\
250 \pm \\
\mathrm{NaNO}_{3}\end{array}$ & $\begin{array}{c}140 \\
\text { Sept. } 20 \\
150 \ddagger \\
\mathrm{NaNO}_{3}\end{array}$ \\
\hline
\end{tabular}

"Plots 6'x6' with $2 \mathrm{ft}$. alleys.

Since the experiment was carried on for only one year, random selections of the plots within each series were used. The plan of the experiment as given in Table 11 shows the treatment and the arrangement of the plots.

These plots were seeded to soybeans of the Wilson variety in the spring of 1929 and the harvest begun on August 10, at which time soybean hay was removed from the five check plots. On September 20 the soybean hay was removed from the remaining 35 plots. All plots were seeded to wheat on September 22 at the rate of 8 pecks per acre. Before seeding wheat, however, the various treatments as outlined in Table 11 were given. 
The wheat on the five plots from which soybeans had been removed on August 10 started off in vigorous condition with good color. That on the five untreated plots, from which soybeans had been removed September 20, started off slowly and with poor color. Wheat on all plots from which soybeans had been removed on September 20 and which had received fertilizer went into the winter in better condition than that on the plots from which soybeans had been removed at the same time, but which received no fertilizer. The heavier applications of nitrogen were evident in the deeper green color and more vigorous growth of the wheat.

TABLE 12-Effect of fertilizers on yield of wheat following soybean?

\begin{tabular}{|c|c|c|c|c|}
\hline \multirow[b]{2}{*}{$\begin{array}{c}\text { Date of removal } \\
\text { of soybeans }\end{array}$} & \multirow[b]{2}{*}{ Treatment* } & \multicolumn{2}{|c|}{ Yield } & \multirow{2}{*}{$\begin{array}{l}\text { Height of } \\
\text { straw } \\
7-3-30\end{array}$} \\
\hline & & Grain & Straw & \\
\hline $\begin{array}{ll}\text { August } 10 & \\
\text { September } 20 \\
\text { September } 20 \\
\text { September } 20 \\
\text { September } 20\end{array}$ & $\begin{array}{c}\text { None } \\
\text { None } \\
50 \# \mathrm{NaNO}_{3} \\
150 \# \mathrm{NaNO}_{3} \\
150 \rrbracket \mathrm{NaNO}_{3} \\
\text { Soil packed }\end{array}$ & $\begin{array}{c}\text { Bu. } \\
19.1 \pm .38 \\
17.3 \pm .15 \\
21.3 \pm .21 \\
21.4 \pm .12 \\
23.3 \pm .74\end{array}$ & $\begin{array}{c}\text { Lbs. } \\
2695 \pm 96 \\
2477 \pm 73 \\
2733 \pm 53 \\
3044 \pm 58 \\
3119 \pm 85\end{array}$ & $\begin{array}{c}\text { Inches } \\
33.6 \\
31.4 \\
34.8 \\
36.4 \\
36.2\end{array}$ \\
\hline $\begin{array}{ll}\text { September } 20 \\
\text { September } 20 \\
\text { Scptember } 20 \\
\end{array}$ & $\begin{aligned} 250 \# \mathrm{NaNO}_{3} \\
400 \# 2-14-4 \\
\text { Soil packed }\end{aligned}$ & $\begin{array}{l}26.8 \pm .66 \\
21.6 \pm .16 \\
17.5 \pm .41 \\
\end{array}$ & $\begin{array}{l}3486 \pm 44 \\
2992 \pm 115 \\
2338 \pm 18\end{array}$ & $\begin{array}{l}38.8 \\
34.2 \\
30.8\end{array}$ \\
\hline
\end{tabular}

*Fertilizer applied at tine of seeding wheat.

TABLE 13-Nitrate and moisture content of soil and yield of wheat on plots 101-140 inclusive, from which soybeans were removed at different dates

\begin{tabular}{|c|c|c|c|c|c|}
\hline Date soybeans & Date & & Moisture & 1930 yield of & wheat \\
\hline were removed & sampled & Nitrates & percentage & Grain & Straw \\
\hline $\begin{array}{l}\text { August } 10 \\
(5 \text { plots })\end{array}$ & 9.22 .29 & $\begin{array}{c}\text { p.p.m. } \\
22.8\end{array}$ & 20.5 & $\begin{array}{l}\text { bu. } \\
19.1\end{array}$ & $\begin{array}{l}\text { lbs. } \\
2695\end{array}$ \\
\hline $\begin{array}{c}\text { September } 20 \\
(35 \text { plots })\end{array}$ & 9.22 .29 & 3.6 & 18.9 & 17.3 & 2477 \\
\hline
\end{tabular}

The yield data for the various treatments are given in Table 12. A study of this table shows rather conclusively that nitrogen was the chief fertilizer ingredient limiting the production of wheat on this soil and that the reduction in wheat yield caused by the late removal of soybeans was overcome by applications of nitrate of soda. Even as little as 50 pounds per acre was sufficient to accomplish this. Two hundred and fifty pounds per acre increased the yield by 9.5 bushels. Packing the soil had no effect on the yield when no nitrogenous fertilizer was applied but did give a slight increase when 150 pounds of nitrate of soda was added. The yield on the plots which received a complete fertilizer was no better than on those which received the same amount of nitrogen. The circumstance indicates no response from phosphate or potash fertilizers. 


\section{NITRATE CONTENT OF SOIL FOLLOWING DIFFERENT METHODS OF TREATMENT}

Nitrate determination on soil samples from these plots just prior to the seeding of wheat showed the same sort of difference due to different dates of harvesting as were obtained on plots 31-54 in Experiment II. These differences are shown in Table 13 and Figure 2. The nitrate content of 22.8 p.p.m. following the early removal of soybeans was seven times as great at the time of planting the wheat than following late removal of soybeans

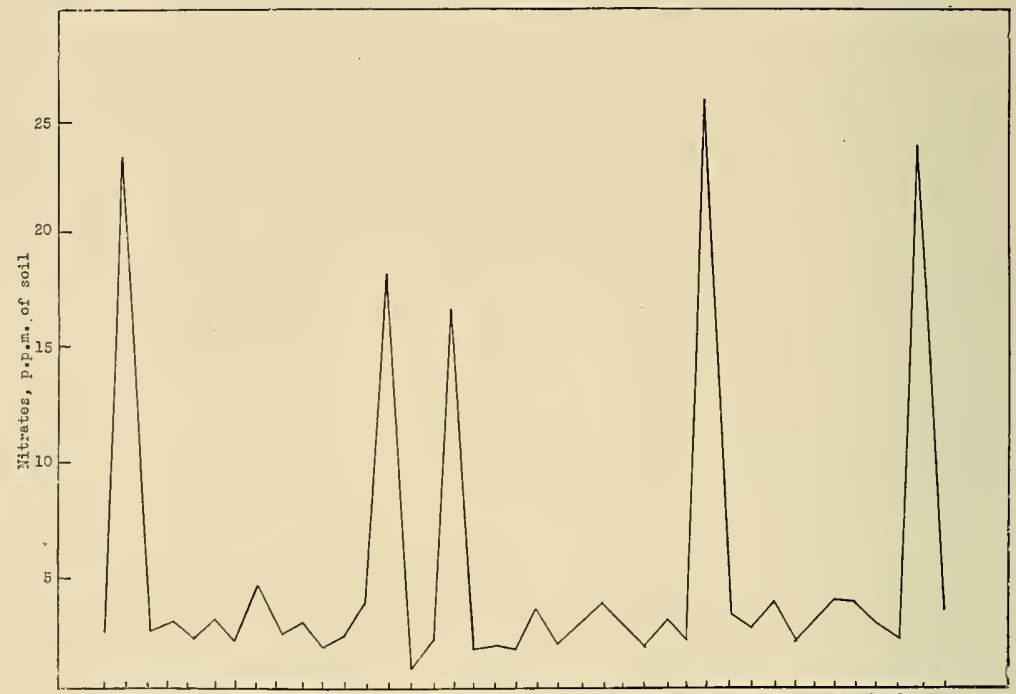

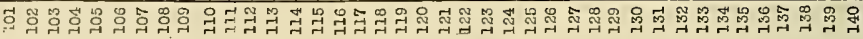

Plot number

FlG. 2-Nitrate content of plots 101-140 on September 22, 1929.

Soybeans removed from plois 102, 114, 117, 129, and 139 on

August 10. Soybeans removed from other plots on September 20

Moisture determinations showed also the same relationship to nitrate content and yield as had been previously observed in the plots of Experiment II. The relatively high moisture content of the plots from which soybeans were removed on September 20 may be accounted for by heavy rains just before the harvest of soybeans from these plots.

\section{PHOSPHATE STUDIES}

Inorganic phosphate determinations on samples taken September 22 from five plots from which soybeans had been removed on August 10 and from five from which they were removed on September 20 showed some very significant differences. The five early and the five late-harvested plots were adjacent pairs. A composite sample for each date of harvesting was also prepared by taking 100 grams of soil from each of the five samples. The results obtained are given in Table 14. 
This table shows that in every case there was more water-soluble phosphate on the plots from which soybeans were removed on August 10. The percentage by which these plots excelled ranged from 35.4 to 79.5 , with an average of 49.0 . These data show clearly a relationship between date of harvesting soybeans and the watersoluble phosphate content. However, the supply of available phosphate was apparently sufficient in all the plots, since the addition of a phosphate fertilizer did not increase the wield of wheat.

TABLE 14-Inorganic phosphates in water extract of soil samples from five carly and five late-harvested soybean plots

\begin{tabular}{|c|c|c|c|c|c|c|c|}
\hline \multirow[b]{2}{*}{ Comparisons } & \multicolumn{7}{|c|}{ Samples and p.p.m. of phosphates } \\
\hline & 1 & 2 & 3 & 4 & 5 & C'mposite & Average \\
\hline $\begin{array}{l}\text { Soybeans removed } \\
\text { August } 10\end{array}$ & .219 & .325 & .282 & .350 & .357 & .315 & .307 \\
\hline $\begin{array}{l}\text { Soybeans removed } \\
\text { August } 20 \\
\end{array}$ & .122 & .240 & .195 & .235 & .240 & .237 & .206 \\
\hline Difference & .097 & .085 & $.0 \times 7$ & .115 & .117 & .078 & .101 \\
\hline $\begin{array}{l}\text { Percentage by which } \\
\text { August } 10 \text { exceeds } \\
\text { September } 20\end{array}$ & 79.5 & 35.4 & 44.6 & 48.9 & 48.8 & 32.9 & 49.0 \\
\hline
\end{tabular}

TABLE 15-Niirogen, phosphorrs, and potassinm found in soybeans harvested on Argust 10 and September $20^{\text {i }}$

\begin{tabular}{lccc}
\hline \hline & Nitrogen & $\mathrm{P}_{2} \mathrm{O}_{5}$ & $\mathrm{~K}_{2} \mathrm{O}$ \\
\hline $\begin{array}{l}\text { Harvested August } 10 \text { at } \\
\text { beginning of blossom }\end{array}$ & $\%$ & $\%$ & $\%$ \\
$\begin{array}{l}\text { Harvested September 20, } \\
\text { pods well flled }\end{array}$ & 2.30 & 0.485 & 1.676 \\
\hline
\end{tabular}

*The determinations reported in this table ware made by the department of agricultural chemistry of the Experiment Station.

\section{NUTRIENTS REMOVED BY SOYBEANS}

Samples of the soybeans removed on August 10 and also of those removed on September 20 were analyzed for total nitrogen, phosphorus, and potassium. The results obtained are given in Table 15, which shows a material difference in the percentage of nitrogen but not in phosphoric acid and potash of the early and the late-removed soybeans. When calculated on the acre basis from yield of these two sets of plots, it appears that there was removed from the early-harvested plots 41.7 pounds of nitrogen, 8.8 pounds of phosphoric acid, and 304 pounds of potash; whereas from the late-harvested plots the average removal was 71.5 pounds of nitrogen, 17.2 pounds of phosphoric acid, and 61.2 pounds of potash. This makes a difference of 29.8 pounds of nitrogen, 8.4 pounds of phosphoric acid, and 30.4 pounds of potash equivalent to 192 pounds of nitrate of soda, 42 pounds of $20 \%$ superphosphate, and 61 pounds of muriate of potash, or 300 pounds of a 10-2.8-10 fertilizer. All this was of necessity in a readily available form. Considering this great difference in the amount removed and the fact that no time elapses after the late removal of soybeans and before the seeding of wheat for a new supply of available nutrients to accumulate, the poor growth of wheat during the fall is not sur- 
prising. It is, therefore, to be expected that nitrogen in a readily available form would have an accelerating effect upon the yield of the wheat crop following late removal of soybeans.

\section{SUMMARY AND CONCLUSIONS}

The yield of wheat, oats, and corn was higher following soybeans harvested for hay than the yield following oats harvested for grain. The difference in yields of wheat and corn appeared to be related to differences in the nitrate content of the soil.

The yield of buckwheat and potatoes was not affected differently by preceding crops of oats or soybeans.

Oats following oats, buckwheat, or corn were poorer than oats following wheat and potatoes.

Soybeans gave a lower vield after corn than after wheat. The other crops tested-oats, buckwheat, and potatoes-were similar to wheat in their effect on the succeeding crop of soybeans.

The yield of wheat following soybeans removed September 20 was lower than the yield following soybeans removed August 10 or August 30. On September 20 the soybeans were about ready to be cut for seed.

The nitrate content of the soil was low at the time of the removal of the soybeans, but increased rapidly after their removal.

The addition of nitrate of soda at the rate of 50 pounds per acre counteracted the harmful effect of late removal of soybeans on the yield of the succeeding wheat crop.

The time of removal of soybeans did not affect the yield of the succeeding corn crop.

Sufficient time should be allowed after the removal of the soybeans for the store of available nitrogen to be replenished before the next crop is planted. Three weeks appeared to be ample time in this experiment. An alternative for this is to add a fertilizer containing nitrogen at the time of seeding.

\section{LITERATURE CITED}

(1) DeATRICK, E. P.

REDUCTION OF SOIL NITRATES DURING THE GROWTH OF SOYBEANS. Jour. Am. Soc. Agron. 20:947-958. 1928.

(2) Fisher, R. A.

STATISTICAL METHODS FOR RESEARCH WORKERS. Ed. 2. London. 1932.

(3) Illinois Agr. Exp. Sta. Annual Rpts. 1925-26, p. 33; 1926-27, p. 45.

(4) LYON, T. L.

THE EFFECT OF SOME LEGUMES ON THE YIELDS OF SUCCEEDING CROPS. Cornell Univ. Agr. Exp. Sta. Bul. 447.1925.

(5) MCCLELlaND, C. K.

VARIETY AND ROTATION EXPERIMENTS WITH SOYBEANS. Ark. Agr. Exp. Sta. Bul. 199. 1925.

(6) Noll, C. F., AND Lewis, R. D.

SOYBEANS: THEIR CULTURE AND USE. Penna. Agr. Exp. Sta. Bul. 187.1924. 
(7) PARKer, F. W., AND FudGe, J. F.

SOIL PHOSPHORUS STUDIES I. Soil Sci. 24:111. 1927.

(8) Pierre, W. H., and Parker, F. W.

THE USE OF COLLODION SACKS IN OBTAINING CLEAR SOIL EXTRACTS FOR THE DETERMINATION OF THE WATERSOLUBLE CONSTITUENTS. Soil Sci. 23:13-22. 1927.

(9) SALTER, R. M.

CROP YIELDS FOLLOWING DIFFERENT CROPS. FIELD WORK. Ohio Agr. Exp. Sta. Sp. Bul., p. 54. 1930.

(10) SchreINER, O., AND FAILYER, O. H.

COLORIMETRIC, TURBIDITY, AND TITRATION METHODS USED

IN SOIL INVESTIGATIONS. U. S. D. A. Bur. of Soils Bul. 31. 1906.

(11) STUDENT.

NEW TABLES FOR TESTING THE SIGNIFICANCE OF OBSERVATION. Metron. 5:105-120. 1925.

(12) Welton, F. A., AND Morris, V. H.

YIELDS OF WHEAT FOLLOWING POTATOES AND THE RELA-

TION OF NITRATES IN THE SOIL TO THESE. Jour. Am. Soc.

Agron. 16:519-534. 1924.

(13) Wiancko, A. T., Conner, S. D., and Jones, S. C.

THE VALUE OF LEGUMES ON INDIANA SOILS. Indiana Agr. Exp.

Sta. Bul. 226.1919.

\section{APPENDIX}

TABLE A-Yield of oats, buckwheat, potatoes, wheat, and corn following soybeans and oats

\begin{tabular}{|c|c|c|c|c|c|c|c|c|c|c|c|}
\hline \multicolumn{3}{|c|}{ |Previous| } & \multicolumn{2}{|c|}{ Oats } & \multicolumn{2}{|c|}{ Buckwheat } & \multirow[t]{2}{*}{ Potatoes } & \multicolumn{2}{|c|}{ Wheat } & \multicolumn{2}{|c|}{ Corn } \\
\hline Year & Crop & Plots & Grain & Straw & Grain & Straw & & Grain & Straw & Grain & Straw \\
\hline \multirow[t]{2}{*}{1927} & Soybeans & $\begin{array}{c}1-5 \\
6-10 \\
11-15 \\
\end{array}$ & \begin{tabular}{r|} 
Bu. \\
47.3 \\
49.9 \\
55.2 \\
\end{tabular} & $\begin{array}{l}\text { Tons } \\
0.949 \\
1.283 \\
1.283\end{array}$ & $\begin{array}{r}\text { Bu. } \\
30.9 \\
30.1 \\
34.5\end{array}$ & $\begin{array}{l}\text { Tons } \\
1.374 \\
1.459 \\
2.005\end{array}$ & $\begin{array}{r}\text { Bu. } \\
63.2 \\
116.4 \\
114.9 \\
\end{array}$ & $\begin{array}{r}\text { Bu. } \\
36.5 \\
32.0 \\
31.6\end{array}$ & $\begin{array}{l}\text { Tons } \\
2.166 \\
2.202 \\
2.313\end{array}$ & $\begin{array}{r}\text { Bu. } \\
41.8 \\
43.1 \\
50.7\end{array}$ & $\begin{array}{l}\text { Tons } \\
0.913 \\
1.086 \\
1.197 \\
\end{array}$ \\
\hline & Oats & $\begin{array}{l}16.20 \\
21.25 \\
26.30 \\
\end{array}$ & $\begin{array}{l}50.8 \\
52.4 \\
46.1 \\
\end{array}$ & $\begin{array}{r}1.252 \\
1.293 \\
1.151\end{array}$ & $\begin{array}{l}29.1 \\
32.7 \\
33.7 \\
\end{array}$ & $\begin{array}{l}1.273 \\
1.838 \\
2.096 \\
\end{array}$ & & $\begin{array}{l}35.3 \\
32.1 \\
23.4 \\
\end{array}$ & & $\begin{array}{l}34.4 \\
36.0 \\
44.0 \\
\end{array}$ & $\begin{array}{l}0.895 \\
0.987 \\
1.197 \\
\end{array}$ \\
\hline \multirow[t]{2}{*}{1929} & Oats & $\begin{array}{r}1-5 \\
6-10 \\
11-15 \\
\end{array}$ & $\begin{array}{l}61.8 \\
53.5 \\
52.2\end{array}$ & $\begin{array}{l}1.007 \\
0.927 \\
0.869 \\
\end{array}$ & $\begin{array}{l}40.4 \\
28.3 \\
35.9\end{array}$ & $\begin{array}{l}1.4 \\
0.8 \\
1.2\end{array}$ & $\begin{array}{r}102 \\
93 \\
130 \\
\end{array}$ & $\begin{array}{l}28.2 \\
22.9 \\
21.3 \\
\end{array}$ & $\begin{array}{l}1.585 \\
1.325 \\
1.370 \\
\end{array}$ & $\begin{array}{l}40.8 \\
41.0 \\
63.9 \\
\end{array}$ & $\begin{array}{l}1.390 \\
1.439 \\
1.870 \\
\end{array}$ \\
\hline & Soy & $\begin{array}{l}16-20 \\
21-25 \\
26-30\end{array}$ & $\begin{array}{l}74.1 \\
66.5 \\
60.8\end{array}$ & $\begin{array}{l}1.267 \\
1235 \\
1.002\end{array}$ & $\begin{array}{l}32.3 \\
34.0 \\
31.7\end{array}$ & $\begin{array}{l}0.996 \\
1.177 \\
1.118 \\
\end{array}$ & & $\begin{array}{l}26.4 \\
22.5 \\
18.6 \\
\end{array}$ & & $\begin{array}{l}52.7 \\
46.2 \\
51.4 \\
\end{array}$ & $\begin{array}{l}1.488 \\
1.242 \\
1.365 \\
\end{array}$ \\
\hline \multirow[t]{2}{*}{1931} & Soybeans & $\begin{array}{c}1-5 \\
6-10 \\
11-15\end{array}$ & $\begin{array}{l}58.2 \\
52.0 \\
51.7 \\
\end{array}$ & $\begin{array}{l}1.220 \\
0.969 \\
0.963 \\
\end{array}$ & $\begin{array}{l}27.4 \\
26.2 \\
23.9 \\
\end{array}$ & $\begin{array}{l}1.4 \\
0.9 \\
0.9\end{array}$ & $\begin{array}{r}113.0 \\
69.1 \\
77.7 \\
\end{array}$ & $\begin{array}{l}30.7 \\
27.6 \\
33.2 \\
\end{array}$ & & $\begin{array}{l}53.6 \\
54.3 \\
59.7\end{array}$ & $\begin{array}{l}1.667 \\
1.643 \\
1.704 \\
\end{array}$ \\
\hline & Oats & $\begin{array}{l}16-20 \\
21-25 \\
26-30 \\
\end{array}$ & $\begin{array}{l}43.5 \\
42.9 \\
38.3 \\
\end{array}$ & $\begin{array}{l}0.817 \\
0.958 \\
0.702 \\
\end{array}$ & $\begin{array}{l}25.1 \\
26.6 \\
25.1 \\
\end{array}$ & $\begin{array}{l}1.068 \\
1.188 \\
1.047 \\
\end{array}$ & & $\begin{array}{l}20.9 \\
26.9 \\
22.0 \\
\end{array}$ & $\begin{array}{l}1.194 \\
1.487 \\
1.068\end{array}$ & $\begin{array}{l}53.0 \\
38.4 \\
36.7 \\
\end{array}$ & $\begin{array}{l}1.643 \\
1.667 \\
1.396 \\
\end{array}$ \\
\hline \multirow[t]{2}{*}{1933} & Oats & $\begin{array}{c}1.5 \\
6.10 \\
11.15 \\
\end{array}$ & $\begin{array}{r}18.7 \\
16.7 \\
5.9 \\
\end{array}$ & $\begin{array}{l}0.361 \\
0.508 \\
0.241 \\
\end{array}$ & $\begin{array}{l}34.8 \\
24.7 \\
29.3 \\
\end{array}$ & $\begin{array}{l}0.995 \\
0.649 \\
0.963 \\
\end{array}$ & & $\begin{array}{l}23.9 \\
19.9 \\
24.6\end{array}$ & $\begin{array}{l}1.513 \\
0.953 \\
1.534 \\
\end{array}$ & $\begin{array}{l}43.3 \\
44.3 \\
47.6 \\
\end{array}$ & $\begin{array}{l}0.895 \\
0.895 \\
0.988 \\
\end{array}$ \\
\hline & Soybear & $\begin{array}{l}16-20 \\
21.25 \\
26.30 \\
\end{array}$ & $\begin{array}{r}27.5 \\
18.3 \\
9.2 \\
\end{array}$ & $\begin{array}{l}0.503 \\
0.482 \\
0.272 \\
\end{array}$ & $\begin{array}{l}32.2 \\
30.4 \\
29.5 \\
\end{array}$ & $\begin{array}{l}0.827 \\
0.961 \\
0.885 \\
\end{array}$ & $\begin{array}{l}72.0 \\
71.9 \\
58.2 \\
\end{array}$ & $\begin{array}{l}31.4 \\
30.0 \\
23.9 \\
\end{array}$ & $\begin{array}{r}2.345 \\
2.377 \\
1.314 \\
\end{array}$ & $\begin{array}{l}49.2 \\
39.3 \\
29.1 \\
\end{array}$ & $\begin{array}{l}1.050 \\
0.790 \\
0.698 \\
\end{array}$ \\
\hline
\end{tabular}


TABLE B-Yield of soybeans and oats following oats, buckwheat, potatoes, wheat, and corn

\begin{tabular}{|c|c|c|c|c|c|c|c|c|c|}
\hline \multirow{3}{*}{$\begin{array}{l}\text { Plot } \\
\text { No. }\end{array}$} & \multirow{3}{*}{$\begin{array}{c}\text { Preceding } \\
\text { Crop }\end{array}$} & \multirow{2}{*}{\multicolumn{2}{|c|}{$\begin{array}{c}1926^{*} \\
\text { Soybeans }\end{array}$}} & \multirow{2}{*}{\multicolumn{2}{|c|}{$\frac{1928}{\text { Oats }}$}} & \multirow{2}{*}{\multicolumn{2}{|c|}{$\begin{array}{c}1930 \\
\text { Soybeans }\end{array}$}} & \multirow{2}{*}{\multicolumn{2}{|c|}{$\begin{array}{r}1932 \\
\text { Oats }\end{array}$}} \\
\hline & & & & & & & & & \\
\hline & & & Hay & Grain & Straw & & Hay & Grain & Straw \\
\hline $\begin{array}{r}1 \\
6 \\
11\end{array}$ & Oats & & $\begin{array}{l}\text { Tons } \\
2.01 \\
2.01 \\
1.91\end{array}$ & $\begin{array}{l}\text { Bu. } \\
47.0 \\
36.7 \\
42.5\end{array}$ & $\begin{array}{l}\text { Tons } \\
0.835 \\
0.784 \\
0.680\end{array}$ & & $\begin{array}{l}\text { Tons } \\
1.70 \\
1.76 \\
1.66\end{array}$ & $\begin{array}{l}\text { Bu. } \\
21.6 \\
21.6 \\
17.2\end{array}$ & $\begin{array}{l}\text { Tons } \\
0.405 \\
0.405 \\
0.320\end{array}$ \\
\hline $\begin{array}{r}2 \\
7 \\
12\end{array}$ & Buckwheat & & $\begin{array}{l}2.05 \\
1.77\end{array}$ & $\begin{array}{l}51.8 \\
36.4 \\
39.9\end{array}$ & $\begin{array}{l}1.139 \\
0.758 \\
0.639\end{array}$ & & $\begin{array}{l}1.83 \\
1.50 \\
1.65\end{array}$ & $\begin{array}{l}21.9 \\
15.3 \\
13.4\end{array}$ & $\begin{array}{l}0.440 \\
0.305 \\
0.275\end{array}$ \\
\hline $\begin{array}{r}3 \\
8 \\
13\end{array}$ & Potatoes & & $\begin{array}{l}1.93 \\
1.84 \\
2.09\end{array}$ & $\begin{array}{l}58.0 \\
44.4 \\
48.9\end{array}$ & $\begin{array}{l}1.16 \\
0.959 \\
0.845\end{array}$ & & $\begin{array}{l}2.01 \\
1.44 \\
1.96\end{array}$ & $\begin{array}{l}30.0 \\
16.9 \\
17.2\end{array}$ & $\begin{array}{l}0.590 \\
0.330 \\
0.385\end{array}$ \\
\hline $\begin{array}{r}4 \\
9 \\
14\end{array}$ & Wheat & & $\begin{array}{l}1.74 \\
1.72 \\
2.08\end{array}$ & $\begin{array}{l}45.7 \\
41.2 \\
43.8\end{array}$ & $\begin{array}{l}1.083 \\
0.866 \\
0.825\end{array}$ & & $\begin{array}{l}1.97 \\
1.59 \\
1.87\end{array}$ & $\begin{array}{l}25.6 \\
17.2 \\
19.1\end{array}$ & $\begin{array}{l}0.520 \\
0.350 \\
0.440\end{array}$ \\
\hline \multirow[t]{3}{*}{$\begin{array}{r}5 \\
10 \\
15\end{array}$} & Corn & & $\begin{array}{l}1.83 \\
1.82 \\
1.89\end{array}$ & $\begin{array}{l}42.5 \\
41.2 \\
41.9\end{array}$ & $\begin{array}{l}0.876 \\
0.804 \\
0.680\end{array}$ & & $\begin{array}{l}1.85 \\
1.62 \\
1.56\end{array}$ & $\begin{array}{l}19.1 \\
14.1 \\
12.8\end{array}$ & $\begin{array}{l}0.375 \\
0.270 \\
0.305\end{array}$ \\
\hline & & \multicolumn{2}{|c|}{ Oats } & \multicolumn{2}{|c|}{ Soybeans } & \multicolumn{2}{|c|}{ Oats } & \multicolumn{2}{|c|}{ Soybeans } \\
\hline & & Grain & Straw & & Hay & Grain & Straw & & Hay \\
\hline $\begin{array}{l}61 \\
21 \\
26\end{array}$ & Oats & $\begin{array}{l}\text { Bu. } \\
64.6 \\
60.6 \\
62.9\end{array}$ & $\begin{array}{l}\text { Tons } \\
0.860 \\
0.732 \\
0.741\end{array}$ & & $\begin{array}{r}\text { Tons } \\
1.88 \\
1.71 \\
1.58\end{array}$ & $\begin{array}{l}\text { Bu. } \\
55.9 \\
57.5 \\
43.7\end{array}$ & $\begin{array}{l}\text { Tons } \\
0.755 \\
0.830 \\
0.580\end{array}$ & & $\begin{array}{l}\text { Tons } \\
2.32 \\
2.16 \\
1.96\end{array}$ \\
\hline $\begin{array}{l}17 \\
22 \\
27\end{array}$ & Buckwheat & $\begin{array}{l}65.8 \\
58.6 \\
63.2\end{array}$ & $\begin{array}{l}0.851 \\
0.718 \\
0.819\end{array}$ & & $\begin{array}{l}1.78 \\
1.56 \\
1.51\end{array}$ & $\begin{array}{l}52.5 \\
47.5 \\
42.8\end{array}$ & $\begin{array}{l}0.710 \\
0.660 \\
0.625\end{array}$ & & $\begin{array}{l}2.10 \\
2.04 \\
2.03\end{array}$ \\
\hline $\begin{array}{l}18 \\
23 \\
28\end{array}$ & Potatoes & $\begin{array}{l}58.9 \\
59.2 \\
63.2\end{array}$ & $\begin{array}{l}0.777 \\
0.745 \\
0.837\end{array}$ & & $\begin{array}{l}1.58 \\
1.62 \\
1.51\end{array}$ & $\begin{array}{l}60.9 \\
54.7 \\
39.7\end{array}$ & $\begin{array}{l}0.895 \\
0.755 \\
0.585\end{array}$ & & $\begin{array}{l}2.14 \\
2.00 \\
2.19\end{array}$ \\
\hline $\begin{array}{l}19 \\
24 \\
29\end{array}$ & Wheat & $\begin{array}{l}59.2 \\
58.6 \\
58.6\end{array}$ & $\begin{array}{l}0.764 \\
0.745 \\
0.764\end{array}$ & & $\begin{array}{l}1.77 \\
2.04 \\
1.53\end{array}$ & $\begin{array}{l}65.9 \\
55.3 \\
53.1\end{array}$ & $\begin{array}{l}1.095 \\
0.795 \\
0.780\end{array}$ & & $\begin{array}{l}2.42 \\
2.10 \\
1.90\end{array}$ \\
\hline $\begin{array}{l}20 \\
25 \\
30\end{array}$ & Corn & $\begin{array}{l}61.5 \\
58.6 \\
58.9\end{array}$ & $\begin{array}{l}0.764 \\
0.709 \\
0.695\end{array}$ & & $\begin{array}{l}1.54 \\
1.44 \\
1.54\end{array}$ & $\begin{array}{l}51.2 \\
38.4 \\
29.4\end{array}$ & $\begin{array}{l}0.710 \\
0.545 \\
0.360\end{array}$ & & $\begin{array}{l}2.14 \\
1.88 \\
1.58\end{array}$ \\
\hline
\end{tabular}

*No preceding crop in 1926. 
TABLE C-Yield of soybeans when removed at different dates

\begin{tabular}{|c|c|c|c|c|c|}
\hline \multirow[b]{2}{*}{ Year } & \multirow[t]{2}{*}{ Plot Nos. } & \multicolumn{4}{|c|}{ Date of cutting soybeans } \\
\hline & & 1 & August 10 & August 30 & September 20 \\
\hline 1926 & $\begin{array}{l}31-33 \\
34-36 \\
37-39 \\
40-42 \\
43-45 \\
46-48 \\
49-51 \\
52-54\end{array}$ & & $\begin{array}{r}\text { Tons } \\
0.620 \\
.702 \\
.750 \\
1.099 \\
0.862 \\
0.452 \\
0.463 \\
0.768\end{array}$ & $\begin{array}{l}\text { Tons } \\
1.134 \\
1.156 \\
1.196 \\
1.143 \\
1.154 \\
1.027 \\
1.031 \\
1.213\end{array}$ & $\begin{array}{l}\text { Tons } \\
1.340 \\
1.526 \\
1.841 \\
1.565 \\
1.303 \\
1.381 \\
1.599 \\
1.502\end{array}$ \\
\hline 1928 & $\begin{array}{l}31-33 \\
34-36 \\
37-39 \\
40.42 \\
43-45 \\
46.48 \\
49.51 \\
52-54\end{array}$ & & $\begin{array}{l}1.183 \\
1.277 \\
1.307 \\
1.127 \\
1.160 \\
1.142 \\
1.180 \\
1.170\end{array}$ & $\begin{array}{l}1.884 \\
1.997 \\
1.747 \\
2.010 \\
1.665 \\
1.973 \\
1.733 \\
1.820\end{array}$ & $\begin{array}{l}1.995 \\
2.156 \\
1.894 \\
2.210 \\
1.782 \\
1.452 \\
1.769 \\
2.185\end{array}$ \\
\hline 1930 & $\begin{array}{l}31-33 \\
34-36 \\
37-39 \\
40-42 \\
43.45 \\
46-48 \\
49.51 \\
52.54\end{array}$ & & $\begin{array}{l}0.789 \\
0.761 \\
1.059 \\
0.901 \\
0.666 \\
0.890 \\
1.032 \\
0.704\end{array}$ & $\begin{array}{l}0.977 \\
1.023 \\
1.032 \\
1.359 \\
1.116 \\
0.824 \\
1.141 \\
1.452\end{array}$ & $\begin{array}{l}1.072 \\
1.116 \\
1.375 \\
1.081 \\
1.223 \\
1.116 \\
1.517 \\
1.528\end{array}$ \\
\hline 1932 & $\begin{array}{l}31-33 \\
34-36 \\
37-39 \\
40-42 \\
43-45 \\
46-48 \\
49-51 \\
52-54\end{array}$ & & $\begin{array}{l}1.082 \\
1.119 \\
0.985 \\
1.246 \\
1.123 \\
0.891 \\
1.114 \\
1.264\end{array}$ & $\begin{array}{l}1.497 \\
1.545 \\
1.299 \\
1.539 \\
1.590 \\
1.450 \\
1.805 \\
1.821\end{array}$ & $\begin{array}{l}1.322 \\
1.243 \\
1.613 \\
1.560 \\
1.037 \\
1.357 \\
1.635 \\
1.373\end{array}$ \\
\hline Average & & & .965 & 1.417 & 1.521 \\
\hline
\end{tabular}


